\title{
Editorial
}

\section{Value-based pricing special issue: Editorial}

Journal of Revenue and Pricing Management (2017) 16, 1-3. doi:10.1057/s41272-016-0058-9

There are three generally accepted orientations to pricing. They are commonly referred to as the 3 Cs of pricing - cost-based, competitionbased, and customer-value-based (Hinterhuber, 2004; Liozu, 2015). There is broad consensus among pricing scholars, consultants, and practitioners that a pricing orientation based on customer value and customer willingness-topay is best and can positively influence pricing power and firm performance (Forbis and Mehta, 1981; Dolan and Simon, 1996; Anderson and Narus, 1998; Cressman, 1999; Nagle and Holden, 2002; Ingenbleek et al, 2003). Although only 17 to 20 per cent of firms claim to have adopted value-based pricing (Hinterhuber, 2008; Liozu and Hinterhuber, 2013), awareness of it is increasing, as is the desire to move from cost-based and competition-based orientations to a more customer-value-centric pricing orientation. There are more and more papers published about customer-value- and value-based pricing. More stories of successful transformation are being presented at pricing and business conferences. More firms are piloting value-based pricing with specific projects and technology platforms. Thus, value-based pricing has emerged from the status of severely neglected pricing orientation and potential methodology to that of emerging orientation and methodology. Of course, there is additional room for improvement if value-based pricing is to reach a level of adoption similar to the Six Sigma and Lean methodologies, for example. But there is hope and momentum.
In this special issue, we intend to shed more light on value-based pricing from the perspectives of both practice and theory. Toward that end, we have assembled contributions from eight practitioners and scholars following a rigorous process of selection and review.

We begin this special issue with a practitioner paper by Chris Provines on the topic of value-based pricing viewed from the procurement side. Little research has focused on the receiving end of value-based strategies (Anderson and Wynstra, 2010). The author reviews and integrates the empirical literature on value-based pricing and modern procurement strategies and goals in order to construct a conceptual framework for pricing practitioners.

The next paper, also aimed at practitioners, offers interesting findings from a survey on the state of value-based pricing. Stephan Liozu explores perceptions and challenges of valuebased pricing in the field of practice. He further validates the impact of value-based pricing on margins and identifies the key drivers of the impact of value-based pricing on business unit profitability and pricing power. While perceptions of value-based pricing are improving and its impact is becoming clearer, there are specific challenges that need to be addressed collectively in order to improve its adoption rate and assimilation level.

Ron Hufner then examines the use of valuebased pricing by teams in the four major U.S. professional sports: football, baseball, basketball, and hockey. The websites of all 122 teams in these sports were examined to determine the 
pricing policy for individual games during the regular season. The paper reports that a large majority of teams have adopted value-based pricing, and that many have adopted the dynamic form of value-based pricing.

Jin Young Chung proposes a conceptual framework to clarify what leads to successful implementation of the PWYW (Pay What You Want) pricing mechanism, a participative pricing model in which a consumer can take full control over the price. Psychological factors from the behavioral economics perspective are included in the framework based on the proposition that they play a role in determining how much a consumer will pay. The goals of this value-based pricing strategy are in line with those of revenue management - increasing the opportunity for greater revenues and higher customer satisfaction by understanding consumers' perceived value. By conducting this meta-analysis of real-world examples, the author identifies components, including price fairness perception, that can lead people to pay something greater than zero under PWYW.

The paper written by Johansson, Olsson, and Andersson focuses on organization considerations of deployment value assessments as part of value-based pricing strategies. The paper outlines how centralized versus delegated value assessment responsibility depends on the organization's value creation character and the variations in value-in-use for different customers within individual market segments. Based on the integration of literature on pricing and value configurations, the authors propose a framework supported by four illustrative cases studies. By considering the implications of value creation models for value assessment, the authors contribute to the understanding of how value assessment responsibilities should be assigned for firms working with value-based pricing.

Stoppel and Roth examine the suitability of product-centric and customer-centric pricing schemes for a value-based pricing strategy. They elaborate a conceptualization of the term pricing scheme and classify different kinds of product- and customer-centric pricing schemes by means of their measurement unit. The focus of this paper is on analyzing innovative customer-centric pricing schemes and their consequences using case studies and expert interviews. The results of this inquiry show that customer-centric pricing schemes are more aligned with customer's value-in-use because these schemes shift the revenue models from transactions to the customer's usage metric, thereby forging stronger relationships.

The final contribution to this special issue is by Reen, Hellstrom, Wikstrom, and Perminova. Their paper discusses the challenges and opportunities involved in the pricing of industrial IT solutions, drawing insights from a case study of an organization moving toward value-based pricing. They give practical advice for implementing value-driven strategy in pricing. They propose new pricing strategies by defining "work packages" that can be implemented for the transition toward a valuebased approach. The findings show that valuebased pricing is related to the ability of the organization to create value for its customers and to charge them according to that value, and implies severe changes in the company's business model.

There you have it! We often read about the lack of practical and theoretical publications about value-based pricing (Liozu et al, 2012). This special issue is the first of its kind, focusing solely on the topic of value-based pricing and proposing specific frameworks, models, and findings to advance the field. The goal of this special issue and of The Journal of Revenue $\mathcal{E}$ Pricing Management is to advance the discipline of pricing from a theoretical and practical standpoint. Obviously, as we can see from the diversity of the papers included here, valuebased pricing is a vast domain, as it can be applied to anything. I encourage scholars to continue researching the field and practitioners to apply the findings proposed in this special issue so that we can read about success stories in the future. Be bold. Join the value-based pricing revolution! 


\section{REFERENCES}

Anderson, J. and Wynstra, F. (2010) Purchasing higher-value, higher-price offerings in business markets. Journal of Businessto-Business Marketing 17(1): 29-61.

Anderson, J.C. and Narus, J.A. (1998) Business marketing: Understand what customers value. Harvard Business Review 76(6): 53-65.

Cressman, G.E., Jr. (1999) Commentary on "industrial pricing: Theory and managerial practice”. Marketing Science 18(3): 455-457.

Dolan, R. and Simon, H. (1996) Power pricing: How managing price transforms the bottom line. New York: Free Press.

Forbis, J. and Mehta, N. (1981) Value-based strategies for industrial products. Business Horizons 24(3): 32-42.

Hinterhuber, A. (2004) Towards value-based pricing-An integrative framework for decision making. Industrial Marketing Management 33(8): 765-778.

Hinterhuber, A. (2008) Value delivery and value-based pricing in industrial markets. Advances in Business Marketing and Purchasing 14: 381-448.

Ingenbleek, P., Debruyne, M., Frambach, R. and Verhallen, T. (2003) Successful new product pricing practices: A contingency approach. Marketing Letters 14(4): 289-305.
Liozu, S.M. (2015) The pricing journey: The organizational transformation toward pricing excellence. Stanford, CA: Stanford University Press.

Liozu, S.M. and Hinterhuber, A. (2013) Pricing orientation, pricing capabilities, and firm performance. Management Decision 51(3): 594-614.

Liozu, S.M., Hinterhuber, A., Boland, R. and Perelli, S. (2012) The conceptualization of value-based pricing in industrial firms. Journal of Revenue \& Pricing Management 11(1): 12-34.

Nagle, T.T. and Holden, R.K. (2002) The strategy and tactics of pricing: A guide to profitable decision making. Englewood Cliffs, NJ: Prentice-Hall.

Stephan M. Liozu

Weatherhead School of Management Case Western Reserve University Cleveland, $\mathrm{OH}$ USA E-mail:sliozu@case.edu 